2. Кашель. Адаптована клінічна настанова, заснована на доказах. 2015. 94 c. URL: http://www.volpulmonology.com.ua.

3. Лещенко СI, Моногарова СН. Показники якості життя у хворих на ідіопатичні інтерстиціальні пневмонії. Укр. пульмонолог. журн. 2008;1:17-22.

4. Peter SP Cho, Surinder S Birring, Hannah V Fletcher, et al. Methods of Cough Assessment. The Journal of Allergy and Clinical Immunology: In Practice. 2019;7(6):1715-1723. https://doi.org/10.1016/j.jaip. 2019.01.049.

DOI https://doi.org/10.30525/978-9934-588-81-5-1.4

\title{
ВПЛИВ ПЕРВИННОЇ ДИСМЕНОРЕЇ НА ЯКІСТЬ ЖИТТЯ УЧЕНИЦЬ СТАРШИХ КЛАСІВ ШКІЛ МІСТА
}

\author{
Басюга I. O. \\ кандидат медичних наук, \\ дочент кафедри акушерства і гінекології імені I. Д. Ланового \\ Івано-Франківський національний медичний університет \\ Жураківський В. М. \\ кандидат медичних наук, \\ дочент кафедри акушерства і гінекології імені I. Д. Ланового \\ Івано-Франківський національний медичний університет \\ Моцюк Ю. Б. \\ кандидат медичних наук, \\ асистент кафедри акушерства і гінекології імені І. Д. Ланового \\ Івано-Франківський національний медичний університет \\ Матвійків Н. I. \\ кандидат медичних наук, \\ асистент кафедри акушерства і гінекології ПО \\ Івано-Франківський національний медичний університет \\ м. Івано-Франківськ, Украӥна
}

Первинна дисменорея є однією з найбільш розповсюджених скарг i гінекологічних проблем серед молодих жінок. Звісно дане захворювання не $\epsilon$ справжньою загрозою життю, однак здатне впливати на якість життя дівчат і в залежності від тяжкості перебігу може призводити до тимчасової недієздатності. 3 іншого боку, дисменорея є причиною емоційно-психічних порушень у деяких жінок, що проявляєть- 
ся дратівливістю, депресією, безсонням, булімією, анорексією та іншими. Сильний біль може сприяти розвитку астенічного стану, знижувати пам'ять і працездатність. Іноді провідним симптомом може бути одна 3 перерахованих скарг, яка турбує хвору більше, ніж біль. За даними різних авторів, дисменорея зустрічається у 9-80\% жінок із менструаціями $[1,2]$.

Серед 110 анкетованих учениць 24 (21,8\%) відзначили наявність больового синдрому під час кожної менструації, 64 (58,2\%) при деяких і 22 (20\%) при жодній. У 72 дівчат (81,8\%) наявні додаткові симптоми(слабкість, головний біль, головокружіння, нудота, блювота, діарея, посилене потіння)[3]. Згідно з шкалою NPIS 16(18,2\%) учениць описали свій біль як слабкий (1-3 бали), 38 (43,2\%) як помірний (4-5 балів), 28 (31,8\%) як сильний (6-7 балів), 4 (4,5\%) як дуже сильний (8-9 балів) і 2 (2,3\%) як нестерпний (10 балів). Для ліквідації больового синдрому і зникнення симптомів 52 (59\%) учениці приймали медикаменти, а саме: но-шпу, спазмалгон, анальгін, цитрамон, таміпул, нурофен, парацетамол 52 (59\%) учениці знали про можливість застовування нестероїдних протизапальних засобів для зняття симптомів болючої менструації, однак лише 14 (26,9\%) серед них використовували їх для ліквідації болю, при чому 8 (15,4\%) дівчат приймали НПЗП у субтерапевтичних дозах [4]. У зв'язку з менструальним болем пропускали заняття протягом останнього року 52 (59\%) учениці: 36 $(62,2 \%)$ з них відпрошувались із декількох уроків, $16(30,8 \%)$ пропустили 1-2 дні [5]. Учениці оцінили свою шкільну активність/успішність протягом болючої менструації як: дуже погано (4,5\%), погано (31,8\%), посередньо (45,5\%), добре (18,2\%). Повсякденна активність протягом болючої менструації була оцінена ученицями як: дуже погано $(4,5 \%)$, погано (36,4\%), посередньо (36,4\%), добре (22,7\%) [6].

Таким чином, первинна дисменорея широко розповсюджена серед учениць 10-11 класів шкіл Івано-Франківська і є однією з причин пропуску занять протягом останнього року. Значна частина дівчат окрім больового синдрому має додаткові симптоми (слабкість, головний біль, головокружіння, нудота, блювота, діарея, посилене потовиділення), що в комплексі має значний негативний вплив як на шкільну активність та успішність, так і на повсякденну активність учениць. Незважаючи на поінформованість частини дівчат про ефективне лікування, більшість використовують для ліквідації симптомів медикаменти, що не належать до першої лінії лікування первинної дисменореї або НПЗП у субтерапевтичних дозах. Результати дослідження свідчать про необхідність здійснення широкої просвітницької роботи 3 дівчатами-підлітками. 


\title{
Література:
}

1. Мельников С.М. Лікування дисменореї: акцент на фармакотерапії больового синдрому. Акушерство, гінекологія, генетика. 2016. № 1. C. 56-60.

2. De Sanctis V., Soliman A., Bernasconi S., Bianchin L. et al. Primary Dysmenorrhea in Adolescents: Prevalence, Impact and Recent Knowledge. J. Pediatr. Endocrinol. Rev. 2015.Vol. 13. P. 512-516.

3. Debski R., Niemiec T., Mazurec M. Comparative efficacy and tolerability of drotaverine $80 \mathrm{mg}$ and ibuprofen $400 \mathrm{mg}$ in patients with primary dysmenorrhea protocol DOROTA. Gynec. Pol. 2007. Vol. 78. P. 933-938.

4. Dysmenorrhea and endometriosis in the adolescent. AGOG Committee Opinion № 76. American College of Obstetricians and Gynecologists. J. Obstet. Gynecol. 2018. Vol. 132. P. 249-258.

5. Пирогова В.І., Цьолко О.Р. Оцінювання ефективності застосування комбінованих препаратів у терапії первинної дисменореї. Здоров’я жінки. 2013. № 3. С. 61-64

6. Тучкина И. А. Медицинские и социальные аспекты формирования дисменореи у девушек-подростков. Збірник наукових праць асоціації акушерів-гінекологів України. 2016. Вип. 2 (38). С. 376-380.

7. Тучкина И. А. Клинико-диагностические аспекты первичной дисменореи в подростковом возрасте. Международный профессиональный журнал MEDICINE (Almaty). Казахстан. 2016. № 6 (168). C. 51-55.

DOI https://doi.org/10.30525/978-9934-588-81-5-1.5

\author{
DENTAL PROFILE OF CHILDREN \\ WITH CHRONIC GASTRODUODENITIS
}

\author{
Bauman S. S. \\ Assistant at the Department of Pediatric Dentistry \\ Ukrainian Medical Dental Academy \\ Sheshukova O. V. \\ Candidate of Medical Sciences, Professor, \\ Professor at the Department of Pediatric Dentistry \\ Ukrainian Medical Dental Academy \\ Poltava, Ukraine
}

